\title{
Original
}

\section{A Study of Pancreatic Exocrine Secretion with Bombesin in Conscious Rats}

\author{
Susumu Taguchi ${ }^{1}$, Gary M. Green ${ }^{2)}$, Katsumi Sasaki ${ }^{1)}$, Ikuta NaKano ${ }^{1)}$, \\ Fumihiko NozU ${ }^{1)}$, Hideki Ohta ${ }^{1)}$, Nagahisa AMANo ${ }^{1)}$ \\ and Keiji Mitamura
}

\begin{abstract}
Bombesin has both direct and indirect effects on pancreatic exocrine secretion in mammals. The latter is mediated through the release of cholecystokinin (CCK). In rats, however, it is unclear whether bombesin's effects are direct or are mediated via release of CCK. This study was undertaken to determine the role of CCK in bombesin-stimulated pancreatic enzyme secretion in conscious rats. Pancreatic flow and protein output were increased significantly, two to three-fold over the basal secretion at 30 minutes after administration of $0.25 \mu \mathrm{g} / \mathrm{kg} / \mathrm{h}$ and $0.5 \mu \mathrm{g} / \mathrm{kg} / \mathrm{h}$ of bombesin in rats. Plasma CCK levels were not changed during that period in which pancreatic secretion was stimulated by bombesin. CR 1505 , a CCK receptor antagonist, at $50 \mathrm{mg} / \mathrm{kg}$, did not suppress pancreatic exocrine secretion stimulated by bombesin. It is concluded that the effect of bombesin on pancreatic secretion is a direct effect, and not mediated via release of $\mathrm{CCK}$ in rats.
\end{abstract}

Key words: bombesin, CCK receptor antagonist

\section{Introduction}

It is well known that bombesin, which is a tetradecapeptide isolated from the skin of the frog Bombina bombina ${ }^{1}$, has a stimulatory effect on pancreatic exocrine secretion in mammals ${ }^{2-5}$. It is assumed that the effect of bombesin on pancreatic enzyme secretion is mediated through the release of endogenous cholecystokinin (CCK) in humans ${ }^{2)}$ and $\operatorname{dogs}^{3-4)}$.

However, the mechanism of bombesin-stimulated pancreatic secretion in rats still remains unclear, i.e., whether bombesin acts directly on the pancreas or indirectly via CCK release. In the present study, therefore, we investigated whether the effect of bombesin on pancreatic secretion is mediated via release of endogenous CCK by: (a) measuring plasma CCK levels after intravenous administration of bombesin, and (b) using the specific peripheral CCK receptor antagonist, CR 1505, to determine if it attenuates the stimulatory effects of bombesin on pancreatic flow and protein output in conscious rats.

\section{Materials and Methods}

Materials

Sixteen male Wistar strain rats, weighing 250 350 g, were obtained from Nippon Bio-

1) 2nd Department of Internal Medicine, Showa University School of Medicine, 1-5-8 Hatanodai, Shinagawa-ku, Tokyo 142, Japan.

2) Department of Physiology, University of Texas Health Science Center at San Antonio, San Antonio, TX 78284, USA. 
supply Center (Tokyo, Japan). CR 1505 was donated by Rotter Research Laboratorium (Milano, Italy). Bombesin and purified bovine trypsinogen were purchased from Sigma Chemical Company (St. Louis, MO, USA).

Surgical procedures

A midline abdominal incision was made under Enflurane (Abbott, North Chicago, IL USA) inhalant anesthesia in overnight fasted rats. A cannula (Silastic Medical Grade Tubing, Dow Corning, Midland, MI, USA: ID of 0.020 in. $\times$ OD of 0.037 in.) was inserted into the common bile duct proximal to the ampulla of Vater to collect pure pancreatic juice. The common bile duct was ligated proximal to the pancreas near the liver, and then another cannula was inserted above the ligature to collect pure bile.

A third cannula ( 0.025 in. ID $\times 0.047$ in. OD) was inserted into the duodenum through an incision in the duodenal wall with the tip near the ampulla of Vater to return bile and pancreatic juice. An additional cannula was inserted into the antrum of stomach in order to inject CR 1505. All cannulas were initially brought into the abdominal cavity through a subcutaneous channel starting at the back near the tail.

Finally, two cannulas $(0.025 \mathrm{in}$. ID $\times 0.047 \mathrm{in}$. OD) were inserted into the right and left jugular vein for drawing blood samples and for infusion of bombesin. After closure, the rats were placed in modified Bollman-type restraint cages and had free access to normal rat chow (Oriental Yeast, Tokyo, Japan) and water in a $22^{\circ} \mathrm{C}$ room with light was scheduled from $0800 \mathrm{~h}$ through $2000 \mathrm{~h}$. Bile-pancreatic juice was continuously returned to the duodenum via a return cannula tube using a liquid-level photo-detector coupled to a peristaltic pump (Gilson, France) during recovery and the experiments. Surgical procedures are described in greater detail elsewhere ${ }^{6)}$. All experiments were conducted after a 12-hour fast on the 3 rd day after operation, and carried out under fasting conditions during the experiment.

\section{Experimental Design}

\section{Experiment $A$}

Bile-pancreatic juice was collected each 30-minute period. After 60 minutes basal collection, bombesin $(0.25 \mu \mathrm{g} / \mathrm{kg} / \mathrm{h}$ or $0.5 \mu \mathrm{g} / \mathrm{kg} / \mathrm{h}$, in saline) was infused at a rate of $1 \mathrm{ml}$ for 6 hours via a jugular vein cannula. Pancreatic flow and protein concentration were measured.

One $\mathrm{ml}$ of blood for CCK assay was withdrawn from the other jugular vein cannula immediately before and 0.5 hour after infusion of bombesin.

Four rats were used for each experiment.

\section{Experiment $B$}

CR 1505 at a dose of $50 \mathrm{mg} / \mathrm{kg},(50 \mathrm{mg} / \mathrm{ml}$ emulsion in $0.5 \%$ methyl cellulose) was injected as a bolus via an intragastric cannula into the stomach at 30 minutes before the start of the infusion of bombesin. Pancreatic juice was collected at 30-minute intervals during a 60-minute basal period and for 6 consecutive hours after infusion of bombesin, 0.25 $\mu \mathrm{g} / \mathrm{kg} / \mathrm{h}$ and $0.5 \mu \mathrm{g} / \mathrm{kg} / \mathrm{h}$; pancreatic flow and protein concentration were measured.

For CCK assay, a $1 \mathrm{ml}$ blood sample was withdrawn from the jugular vein cannula at the same time as in experiment A.

Four rats were used for each experiment. 


\section{Assays}

Pancreatic flow was measured by microsyringe (MS-2f 50, Ito Industry Tokyo, Japan) and expressed as $\mu \mathrm{l} / \mathrm{kg} / 30 \mathrm{~min}$.

Protein concentration in pancreatic juice was estimated by determining optical density at

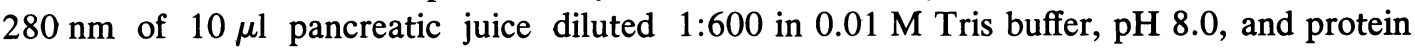
output was expressed as $\mathrm{mg} / \mathrm{kg} / 30 \mathrm{~min}$.

CCK was extracted from $1 \mathrm{ml}$ plasma sample by adsorption onto a C-18 Sep Pak cartridge (Waters Associates, Milford, Mass, USA) and was determined using anti-CCK-8 specific antiserum (OAL-656) by radioimmunoassay ${ }^{7}$.

Statistical analysis

All values were expressed as mean \pm SE. Data were analyzed by paired or unpaired $t$-test. Differences were considered significant at $\mathrm{p}<0.05$.

\section{Results}

\section{Pancreatic exocrine secretion study with bombesin}

Pancreatic flow was significantly increased at the initial 15-minute period. It was 2 times higher than that of basal secretion, $246 \pm 55 \mu \mathrm{l} / \mathrm{kg}$ vs. $564 \pm 74 \mu \mathrm{l} / \mathrm{kg}(\mathrm{p}<0.01)$, and $297 \pm$ $58 \mu \mathrm{l} / \mathrm{kg}$ vs. $626 \pm 85 \mu \mathrm{l} / \mathrm{kg}(\mathrm{p}<0.05)$, with infusion of bombesin at $0.25 \mu \mathrm{g} / \mathrm{kg} / \mathrm{h}$ and $0.5 \mu \mathrm{g} / \mathrm{kg} / \mathrm{h}$, respectively. The stimulant effects appeared biphasic, and they were sustained

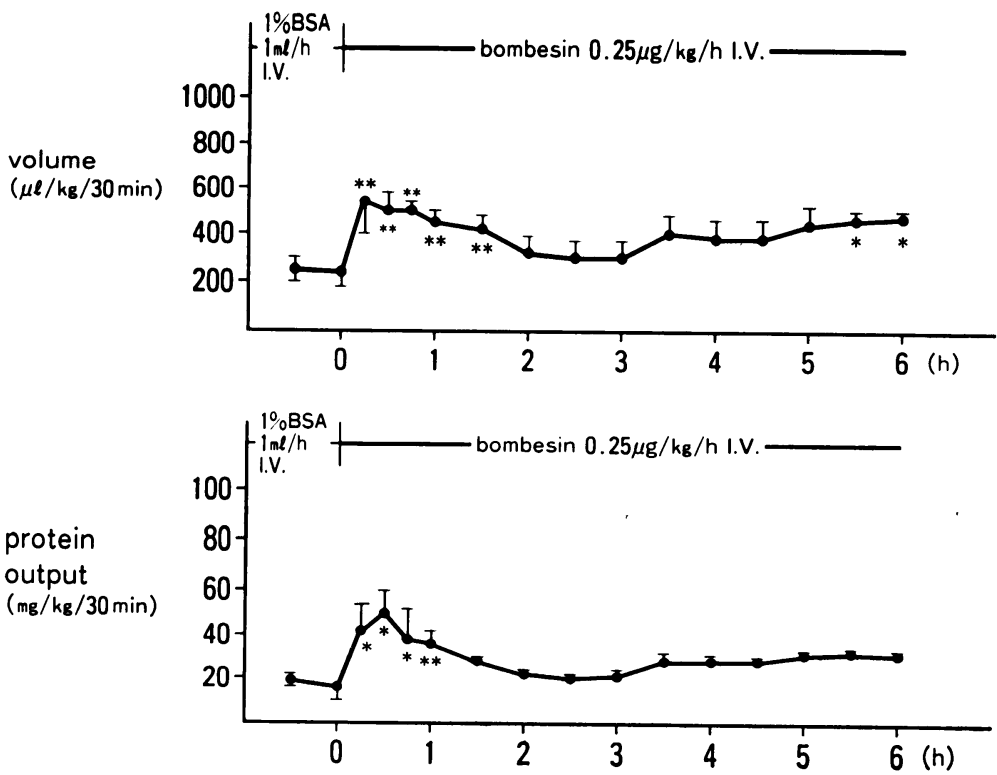

Fig. 1. Effect of bombesin $(0.25 \mu \mathrm{g} / \mathrm{kg} / \mathrm{h}$ intravenous infusion) on pancreatic exocrine secretion in conscious rats. Pancreatic flow increased significantly for 1.5 hour after administration of bombesin. Protein output significantly increased at 15 minutes and it was sustained for 1 hour after the treatment. Results are the mean \pm SE of 4 experiments in 4 rats. Asterisks indicate significantly higher than the basal value before treatment with bombesin. ${ }^{*} \mathrm{p}<0.05$ (vs. basal secretion), ${ }^{* *} \mathrm{p}<0.01$ (vs. basal secretion), I.V.: intravenous injection. 

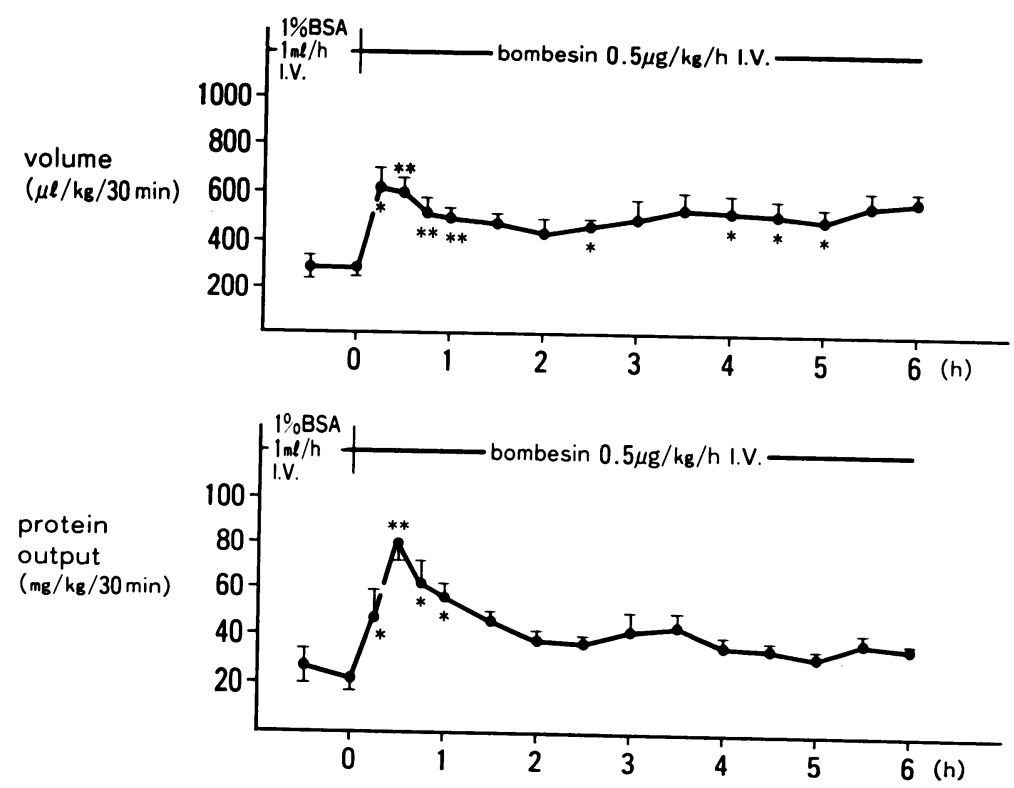

Fig. 2. Effect of bombesin $(0.5 \mu \mathrm{g} / \mathrm{kg} / \mathrm{h}$ intravenous infusion) on pancreatic exocrine secretion in conscious rats. Pancreatic flow and protein output were significantly increased at initial 15 minutes. The peak was recognized at 15 minutes and 30 minutes after administration of bombesin, respectively. Results are the mean $\pm \mathrm{SE}$ of 4 experiments in 4 rats. Asterisks indicate significantly higher than the basal value before treatment with bombesin. $* \mathrm{p}<0.05$ (vs. basal secretion), $* * \mathrm{p}<0.01$ (vs. basal secretion), I.V.: intravenous injection.

\section{5 hour and 1 hour, respectively.}

At 0.5 hour after administration of bombesin $(0.25 \mu \mathrm{g} / \mathrm{kg} / \mathrm{h}, 0.5 \mu \mathrm{g} / \mathrm{kg} / \mathrm{h})$ the peak level of protein output was 2.8 times, $17.46 \pm 4.8 \mathrm{mg} / \mathrm{kg}$ vs. $49.25 \pm 10.45 \mathrm{mg} / \mathrm{kg},(\mathrm{p}<0.05)$, and 3.2 times, $24.88 \pm 5.75 \mathrm{mg} / \mathrm{kg}$ vs. $80.41 \pm 8.21 \mathrm{mg} / \mathrm{kg}$, $(\mathrm{p}<0.01)$, higher than that of the basal level, respectively (Figs. 1 and 2). Plasma CCK levels were $10.2 \pm 0.4 \mathrm{pg} / \mathrm{ml}$ and $12.7 \pm 4.4$ $\mathrm{pg} / \mathrm{ml}$ at $0.5 \mathrm{~h}$ after bombesin treatment $(0.25 \mu \mathrm{g} / \mathrm{kg} / \mathrm{h}$, and $0.5 \mu \mathrm{g} / \mathrm{kg} / \mathrm{h})$ respectively. They did not differ significantly compared with the basal levels (Fig. 3 ).

Effect of CR 1505 on pancreatic secretion stimulated by bombesin

Bombesin-stimulated $(0.5 \mu \mathrm{g} / \mathrm{kg} / \mathrm{h})$ pancreatic secretion was not inhibited by intragastric administration of the CCK receptor antagonist, CR $1505,50 \mathrm{mg} / \mathrm{kg}$ (Fig. 4). Plasma CCK levels in rats treated with CR 1505 plus bombesin did not change at 0.5 hour after treatment with bombesin compared to the basal levels.

The increment (basal subtracted) of protein output in pancreatic fluid during the 2-hour period after bombesin administration did not differ with or without CR 1505 (Fig. 5). The stimulatory effects of bombesin on pancreatic protein output in rats were dose dependent.

\section{Discussion}

The action of bombesin closely resembles that of $\mathrm{CCK}^{8)}$ and the ratios of flow to protein secretion for the two peptides are linear and virtually superimposable ${ }^{9,10)}$. On the other 


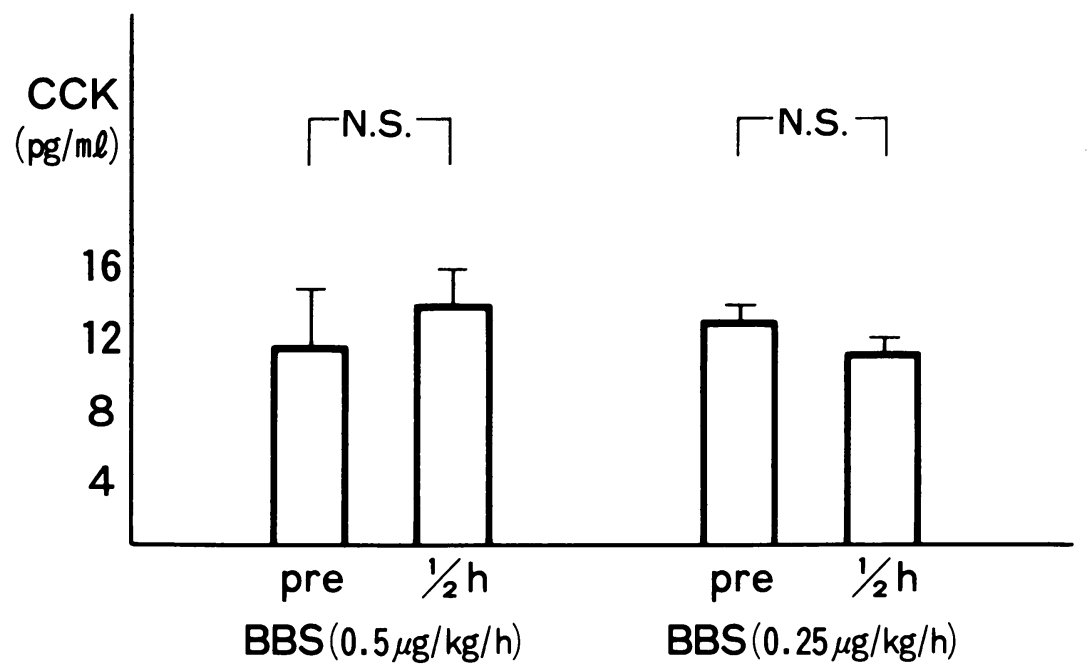

Fig. 3. Plasma CCK levels in bombesin-treated $(0.25 \mu \mathrm{g} / \mathrm{kg} / \mathrm{h}$ and $0.5 \mu \mathrm{g} / \mathrm{kg} / \mathrm{h})$ conscious rats. No significant difference in the plasma CCK levels was found at 0.5 hour after bombesin treatment compared to basal levels. Results are the mean \pm SE of 4 experiments in 4 rats. N.S.: not significant.

hand, cerulein, a CCK analogue, has approximately three- to ten-fold more potency than bombesin in stimulating pancreatic enzyme secretion in rats ${ }^{11,12)}$. Regarding pancreatic exocrine secretion, bombesin has both direct and indirect effects, mediated via endogenous CCK in humans ${ }^{2)}, \operatorname{dogs}^{3,4,13)}$ and pigs $^{5)}$. It is not clear, however, whether the effect is direct or indirect on pancreatic exocrine secretion in rats ${ }^{14,15)}$. In the present study, we investigated whether the stimulatory effect of bombesin on pancreatic exocrine secretion is a direct effect or mediated through the release of endogenous CCK in conscious rats.

Recently, de Jong et al. reported a modest increase of plasma CCK levels during low-dose bombesin infusion $(18 \mathrm{pmol} / \mathrm{kg})$ in rats $^{16)}$. They reported, however, that the plasma CCK increment, induced by a physiological dose infusion of CCK, is similar to that after a lowdose infusion of bombesin, and the protein output stimulated by this CCK dose is significantly lower than that of bombesin low-dose. To achieve stimulation of pancreatic protein similar to that caused by bombesin, infusion of a high dose of CCK was necessary. Therefore, they presumed that factors other than endogenous CCK predominate in the stimulation of pancreatic secretion by bombesin in the rat ${ }^{16)}$. In contrast, some reports have described that low $(6-400 \mathrm{pmol} / \mathrm{kg})$ and high $(5 \mu \mathrm{g} / \mathrm{kg})$ doses of bombesin do not significantly increase plasma $\mathrm{CCK}^{9,11)}$.

In the present study, pancreatic flow and protein output were stimulated to 2- or 3-fold higher than the basal secretion after administration of bombesin. However, plasma CCK did not increase with either $0.25 \mu \mathrm{g} / \mathrm{kg}$ or $0.5 \mu \mathrm{g} / \mathrm{kg}$ of bombesin. Moreover, the bombesinstimulated pancreatic secretion was not suppressed by the administration of CR1505 in conscious rats. In a previous study, we reported that the hyper-pancreatic exocrine secretion, with markedly elevated plasma CCK levels which was induced by chronic bile and pancreatic juice diverted to the ileum, is fully inhibited by intragastric injection of CR1505, 

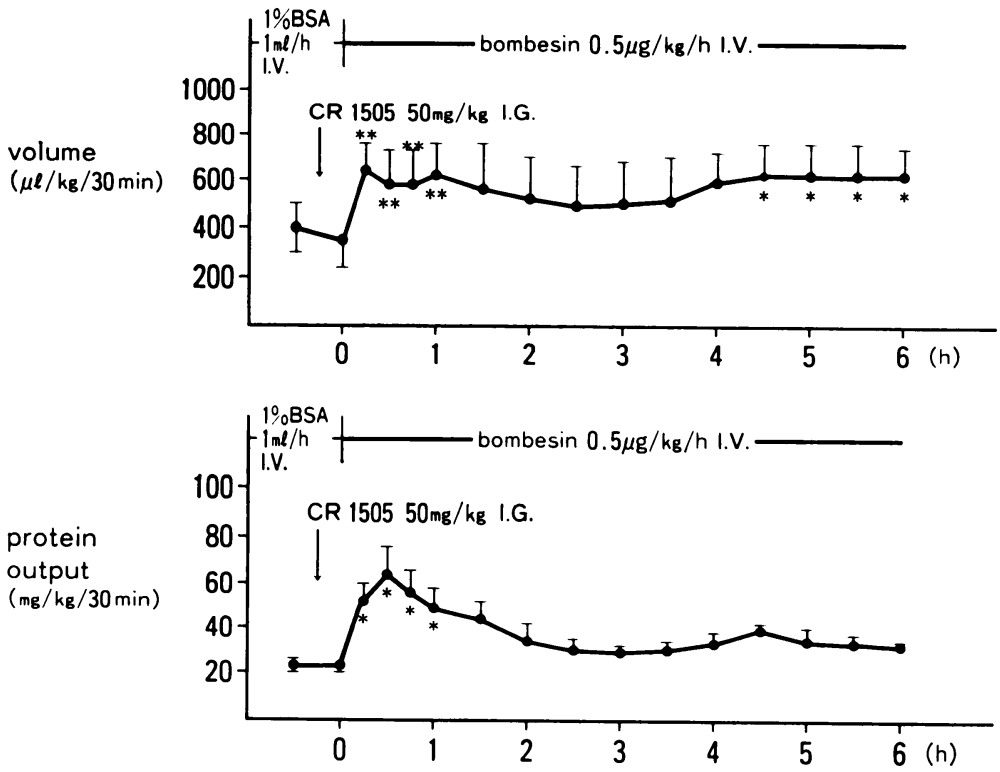

Fig. 4. Effect of $\mathrm{CR} 1505$ on bombesin-stimulated pancreatic secretion in conscious rats. $50 \mathrm{mg} / \mathrm{kg}$ dose of CR 1505 given at 30 minutes before the start of bombesin infusion. Bombesin-stimulated pancreatic secretion was not suppressed by CR 1505. Resutls are the mean $\pm \mathrm{SE}$ of 4 experiments in 4 rats. Asterisks indicate significantly higher than the basal value before treatment with bombesin. ${ }^{*} \mathrm{p}<0.05$ (vs. basal secretion), ** $\mathrm{p}<0.01$ (vs. basal secretion), I.V.: intravenous injection, I.G.: intragastric injection.

a specific receptor antagonist, in conscious rats $^{17)}$. Recently, bombesin receptors have been identified on acinar cells of rat pancreas ${ }^{18}$, and have shown a direct stimulatory effect of bombesin on pancreatic acini in rats ${ }^{19)}$. Further, some groups have reported that bombesinstimulated pancreatic secretion is not inhibited by administration of even the most potent CCK receptor antagonist, $\mathrm{L}-364718$, in rats $^{9,20-22}$.

The effect of bombesin on pancreatic enzyme secretion was studied to determine whether its stimulatory action occurs via a cholinergic pathway in some species. In the dog, atropine has been shown to significantly reduce the release of pancreatic polypeptide in response to bombesin $^{3,23)}$. In rats, however, bombesin-stimulated pancreatic secretion is not significantly inhibited by prior infusion of atropine ${ }^{11}$.

Gastrin-releasing peptide, which shares the carboxy-terminal protein and the biological action of bombesin, stimulated the release of CCK in absence of food in the duodenum, however, no response occurred in the non-fasting rats ${ }^{24)}$. In contrast, plasma CCK levels did not differ after administration of bombesin either under fasting or feeding conditions in the present rat study.

It was reported that bombesin stimulates gastrin release and gastric acid production and that bombesin-mediated gastrin release and gastric acid secretion could elevate the circulating secretin levels in $\operatorname{dogs}{ }^{4)}$. On the other hand, pancreatic bicarbonate output stimulated by bombesin is suppressed by administration of proglumide in $\operatorname{dog} \mathrm{s}^{13)}$, and it was considered that the effect of bombesin-stimulated endogenous secretin release was secondary to gastrin- 


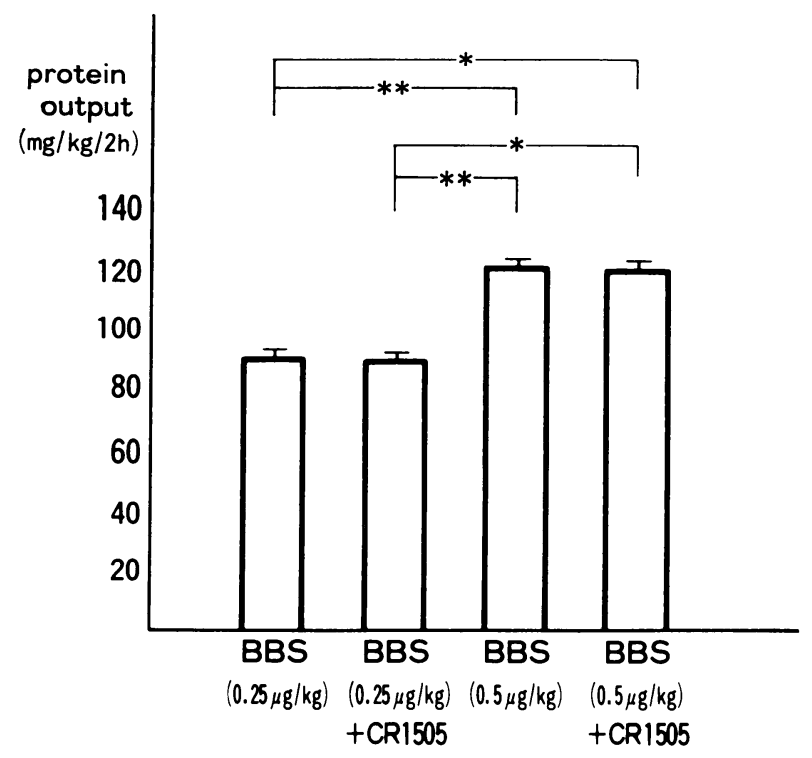

Fig. 5. Increment of pancreatic protein output after administration of bombesin $(0.25 \mu \mathrm{g} /$ $\mathrm{kg} / \mathrm{h}$ and $0.5 \mu \mathrm{g} / \mathrm{kg} / \mathrm{h}$ ) with or without CR $1505,50 \mathrm{mg} / \mathrm{kg}$, in conscious rats. No significant difference in the protein output with or without $\mathrm{CR} 1505$. Asterisks indicate increment of protein output significantly higher in $0.5 \mu \mathrm{g} / \mathrm{kg} / \mathrm{h}$ compared to $0.25 \mu \mathrm{g} / \mathrm{kg} / \mathrm{h}$ dose of bombesin. Results are the mean $\pm \mathrm{SE}$ of each 4 experiments in 4 rats. * $\mathrm{p}<0.05, * * \mathrm{p}<0.01$.

stimulated gastric acid production. In contrast, endogenous secretin release is not a major factor in bombesin-stimulated pancreatic secretion in pyloric ligated rats ${ }^{19)}$. It was considered that secretin is not related to bombesin-stimulated pancreatic secretion in rats.

In the present study, we conclude that bombesin increased the pancreatic exocrine secretion by a direct action on the pancreas rather than by release of gastric hormones, especially CCK, in conscious rats.

\section{References}

1) Anastasi A, Erspamer V and Bucci M: Isolation and amino acid sequence of alytesin and bombesin two analogus active tetradecapeptides from the skin of European discoglossid frogs. Arch Biochem Biophys, 148: 443-446 (1972)

2) Basso N, Giri S, Improta G, Lezoch E, Melchiorri P, Percoco $M$ and Speranza V: External pancreatic secretion after bombesin infusion in man. Gut, 16: 994-998 (1975)

3) Erspamer V, Improta G, Melchiorri $P$ and Sopranzi N: Evidence of cholecystokinin release by bombesin in the dog. Br J Pharmacol, 52: 227-232 (1974)

4) Miyata M, Rayford PL and Thompson JC: Hormonal (gastrin, secretin, cholecystokinin) and secretory effects of bombesin and duodenal acidification in dogs. Surgery, 87: 209-215 (1980)

5) Lilia P, Greeley GH and Thompson JC: Pancreatic exocrine secretion. Release of gastrin and cholecystokinin in response to bombesin in pigs. Arch Surg, 119: 825-828 (1984)

6) Levan VH and Green GM: Effect of atropine on rat pancreatic secretory response to tryspin inhibitors and protein. Am J Physiol, 251: G64-G69 (1986)

7) Himeno S, Tarui $S$, Kanayama S, Kuroshima $T$, Shinomura $Y$, Hayashi $C$, Tateishi $K$, Imagawa $K$, Hashimura E and Hamaoka T: Plasma cholecystokinin responses after ingestion of liquid meal and intraduodenal infusion of fat, amino acid or hydrochloric acid in man: Analysis with region specific 
radioimmunoassay. Am J Gastroenterol, 78: 703-707 (1983)

8) Namba M, Ghatei MA, Ghiglione $M$ and Bloom SR: Effects of decapeptide of mammalian bombesin and neuromedin B on pancreatic exocrine secretion in the rat. Digestion, 34: 105-114 (1986)

9) Anderson L and Dockray GJ: The cholecystokinin antagonist L-364, 718 inhibits the action of cholecystokinin but not bombesin on rat pancreatic secretion in vivo. Eur J Pharmacol, 146: 307-311 (1988)

10) Konturek SJ, Krol $R$ and Tasler $\mathrm{J}$ : Effect of bombesin and related peptides on the release and action of intestinal hormones and pancreatic secretion. J Physiol, 257: 663-672 (1976)

11) Herzig $\mathrm{KH}$, Louie DS and Owyang C: In vivo action of bombesin on exocrine pancreatic secretion in the rat: Independent of cholecystokinin and cholinergic mediation. Pancreas, 3: 292-296 (1988)

12) Christophe J, Deschodt-Lanckman $M$ and Adler $M$ : In vitro and in vivo effects of bombesin and bombesin-like peptides on the rat pancreas. Mechanism of action. In: Bonfils S, Fromageot $P$, Rosselin G, eds. First international symposium on hormonal receptors in digestive tract physiology. Amsterdam, Elsevier Biomedical Press, pp 247-259 (1977)

13) Nealson WH, Beauchamp RD, Townsend CMJr and Thompson JC: Role of cholecystokinin in canine pancreatic exocrine response to bombesin stimulation. Am J Surg, 153: 96-101 (1987)

14) Lhoste E, Aprahamian M, Pousse A, Hoeltzel A and Stock-Damge C: Trophic effect of bombesin on the rat pancreas: is it mediated by the release of gastrin or cholecystokinin? Peptides, 6: 89-97 (1985)

15) Upp JRJr, Poston GJ, MacLellan DG, Townsend CMJr, Barranco SC and Thompson JC: Mechanisms of the trophic actions of bombesin on the pancreas. Pancreas, 3: 193-198 (1988)

16) de Jong AJL, Jansen JBMJ, Hafkenscheid JCM and Lamers CBHW: Role of cholecystokinin in bombesin-stimulated pancreatic enzyme secretion in conscious rats. Pancreas, 5: 194-199 (1990)

17) Taguchi S, Green GM, Nakano I and Hatta Y: Inhibitory effects of the cholecystokinin antagonist loxiglumide on pancreatic exocrine secretion and pancreatic growth in conscious rats. Int $J$ Pancreatol, 11: 67-73 (1992)

18) Gardner JD and Jensen RT: Secretagogue receptors on pancreatic acinar cells. I: Johnson LR, ed. Physiology of the gastrointestinal tract. New York, Raven Press, pp 1109-1127 (1987)

19) Jensen RT, Moody T, Pert C, Rivier JE and Gardner JD: Interaction of bombesin and litorin with specific membrane receptors on pancreatic acinar cells. Proc Natl Acad Sci USA, 75: 6139-6143 (1978)

20) Wisner JR, Ozawa $S$ and Renner IG: Evidence against cholecystokinin mediation of basal and bombesin-stimulated pancreatic secretion in the rat. Gastroenterology, 95: 151-155 (1988)

21) Lotti VJ, Pendleton RG, Gould RJ, Hanson HM, Chang RSL and Clineschmidt BV: In vivo pharmacology of L364,718, a new potent nonpeptide peripheral cholecystokinin antagonist. J Pharmicol Exp Ther, 241: 103-109 (1987)

22) Terashima H, Debas HT and Bunnett NW: Effects of cholecystokinin and gastrin antagonist on pancreatic exocrine secretion stimulated by gastrin-releasing peptide. Pancreas, 7: 212-219 (1992)

23) Taylor IL, Walsh JH, Carter D, Wood J and Grossman MI: Effects of atropine and bethanechol on bombesin-stimulated release of pancreatic polypeptide and gastrin in dog. Gastroenterology, 77: 714-718 (1979)

24) Lewis LD and Williams JA: Regulation of cholecystokinin secretion by food, hormones, and neural pathways in the rat. Am J Physiol, 258: G512-G518 (1990)

[Received February 3, 1995: Accepted March 3, 1995] 